\title{
Comparative Toxicity Study between Some Organophosphorus and Abamectin Insecticides Using Earthworm (Lumbricus Terrestirs) as A Biomarker
}

\author{
A.Kenawy ${ }^{1}$ and M. Sharaf ${ }^{2}$
}

\begin{abstract}
Organophosphorus insecticides are widely used in industry, agriculture, horticulture, domestic, and for public health applications. The consumption of insecticides in the household has almost risen exponentially. Over this half century there has been a significant increase in developmental disorders observed in humans which are thought to have an association with the exposure to pesticides in home environment causing family stress. In addition, abamectin as biocide is recently used as an insecticide. Very little information is available with regard to the sub-lethal effects of abamectin; therefore, the purpose of this work is to compare the toxicity of abamectin as a biocide with malathion and dimethoate as organophosphorus insecticides using the earthworm (Lumbricus terrestirs) as a biomarker. The earthworm was exposed to the tested compound in artificial soil for 7 days. The $\mathrm{LC}_{50}$ of these insecticides was determined. The effects of two concentrations $\left(\mathrm{LC}_{50} \& \mathrm{LC}_{25}\right)$ of these insecticides were studied on the activity of acetylcholinesterase (AChE), glutathione-S-transferase (GST), acid and alkaline phosphatases (AcP \& AIP), and the levels of the two neurotransmitters; gamma amino butyric acid (GABA) and L-glutamic acid. The data showed that the $\mathrm{LC}_{50}$ of abamectin, dimethoate and malathion was 2.99, 13.7, and $39.69 \mathrm{mg} / \mathrm{kg}$, respectively. This means that abamectin was the most toxic, while malathion was the least toxic. Both $\mathrm{LC}_{50} \& \mathrm{LC}_{25}$ concentrations of dimethoate and malathion had significant inhibitory effect on the AChE activity, while abamectin had significant excitatory effects. AcP and AIP activities were significantly increased with the $\mathrm{LC}_{50}$ and $\mathrm{LC}_{25}$ of all the tested insecticides. GST induction activity was significant by the treatment of dimethoate and malathion, while there was significant decrease after treatment with $\mathrm{LC}_{50}$ of abamectin. But there was a non-significant difference with $\mathrm{LC}_{25}$ of abamectin. The lethal and sub-lethal concentrations of the tested insecticides caused a significant induction in GABA and L-glutamic acid concentrations. The data showed that abamectin has the highest effect on the concentration of GABA and L-glutamic acid while dimethoate had the lowest effect. From these results, it could be concluded that abamectin had toxic effect compared to the tested organophosphorus insecticides, also the earthworm can be
\end{abstract}

\footnotetext{
${ }^{1}$ Mammalian Toxicology Division, Central Agricultural Pesticides

Lab .(CAPL), ARC, Ministry of Agriculture, Sabahia,

Alexandria.Egypt.

2 Department of home economics, Faculty of Specific Education,

Alexandria University, Egypt.

* Proofs and all correspondence to:

E-mail: mon_abdelgalil@ hotmail.fr

Received August27, 2008, Accepted September14, 2008
}

considered a good sensitive biomarker to test the toxicity of different compounds.

Keywords: household insecticides; Malathion; Dimethoate; abamectin, earthworm

Abbreviations: AChE, acetylcholinesterase; GST, glutathione-S-transferase; GABA, gamma amino butyric acid; AcP, acid phosphatases; AlP, alkaline phosphatases; LC $_{50}$, lethal concentration; CNS, Central Nervous System.

\section{INTRODUCTION}

Several epidemiological studies have suggested that health concerns may arise from the chronic exposure of young children to pesticides in their home environment (Charlotte et al 2006). Bryan Ballantyne and Salem (2006) showed that organophosphate (OP)and carbamate $(\mathrm{CM})$ anticholinesterases (anti-ChEs)have a wide spectrum of applications that include pesticides in agriculture and horticulture, insecticides in domestic and public health applications, use in general commerce, use in therapeutic medicine, and as chemical warfare and terrorist agents. It can be used safely with the appropriate recommended protective and precautionary measures. However, because of their widespread and sometimes uncontrolled usage, but there is a potential for misuse. Although the principal mechanism of action that underlies the practical use of OPs is namely inhibition of the cholinesterase group of enzymes, it can also be responsible for some of their known human toxicity, because of the wide range of chemical structure involved the potential for numerous and different toxic effects, that are mediated by other mechanisms that can exist e.g. inflammation, immunotoxicity, myopathy, genetic toxicity, ancogencity and developmental and reproductive toxicity.

Unwise use of insecticides can cause human health hazards which place a stress on family budgets and reduce individual physical and mental capacity as well as efficiency in his work.

Abamectin, a recently biocide used as a commercialized insecticide in the region, besides other 
insecticides available in the market, thus, there is a need for tools to monitor the impact of such compound on non-target organisms.

Biomarkers are biological responses that can be related to the toxic effect of one or several pollutants (Peakall 1994). Therefore many biochemical markers of exposure in the earthworms have been recommended as useful sub-lethal criteria (Saint-Denis et al., 1998; Paoletti, 1999).

Organophosphate and carbamate pesticides act by inhibiting cholinesterase's (ChE), which are a group of enzymes in the central nervous system (Edwards and Fisher 1991). Glutathione-S-transferase (GST) is involved in the detoxification of various xenobiotic chemicals. It is a very important enzyme to earthworm because of their role as general scavengers for lipophilic xenobiotics or endogenous formed waste products in earthworms (Stenersen et al., 1979).

Enzymes assay in earthworm are being developed to give a measure of pesticide exposure and as biomarkers of toxicity. Therefore, the aim of the present study is (i) to investigate the effect of the lethal and sub-lethal concentrations of the abamectin, malathion and dimethoate on some biochemical markers: acetylcholinesterase (AChE), Glutathione-S-transferase (GST), acid phosphatases (AcP) and alkaline phosphatases (AlP); (ii) to study the level of two neurotransmitters gamma amino butyric acid (GABA) and L-glutamic acid in the earthworm, and (iii) study the comparative toxicity of the abamectin which was used as safer alternative compounds with some conventional OP's insecticides available commercially for agriculture and home uses specially, malathion and dimethoate as insecticides, by using earthworms as a biomarker.

\section{MATERIALS AND METHODS}

\subsection{Experimental animal}

Earthworms (Lumbricus terrestirs) were collected from the garden of the Agriculture Research Center, Sabahia, Alexandria. The worms were acclimatized at the laboratory conditions (at room temperature and 12 hours light/12 hours dark) in the artificial soil (using an evenly blended dry weight mixture of $20 \%$ kaolin clay, $70 \%$ silica sand, $10 \%$ sphagnum peat and $0.3 \%$ calcium carbonate according to OECD (1984) guideline 207, before testing.

\subsection{Insecticides}

Organophosphorus insecticides; malathion (egythion, $57 \% \mathrm{EC}$ ) and dimethoate (egythoate, $40 \%$ EC) was obtained from the Egyptian Center for Agriculture Services, Biocide; abamectin (Cam-mec, 1.8\% EC) was obtained from Trading Company for Agriculture Requirements. All other chemicals used in this study were obtained from Sigma, Aldrich and BDH companies with high purity.

\subsection{Experimental organism}

Earthworms were divided into two groups; the first group was used to determine the toxicity of the tested insecticides (lethal concentrations; $\mathrm{LC}_{50}$ ). The second one was to study the impact of the lethal and sub-lethal concentrations $\left(\mathrm{LC}_{50}\right.$ and $\left.\mathrm{LC}_{25}\right)$ of these insecticides on the activity of some enzymes in tissues of earthworm. The experiments were performed with adult worms approximately $7.13 \pm 1.5 \mathrm{~cm}$ in length and $0.523 \pm 0.08$ gm in weight with clitellum's.

\subsection{Determination of the lethal pesticide concentrations}

The toxicity was evaluated according to OECD (1984) guideline 207 by the artificial soil test.The insecticide was mixed into artificial soil as an aqueous solution to give the desired working concentration (six concentrations for each insecticide) with three replicates each including control tests soil contained water without pesticide. Each concentration was prepared in 450 grams of the artificial soil and was divided into three quantities in plastic cups.

Five worms were added to each cup and covered with cloth netting secured with rubber band to prevent worms from escaping. Mortality was assessed after 7 days and the $\mathrm{LC}_{50}$ values were calculated according to Finney, (1971) and expressed as $\mathrm{mg} / \mathrm{kg}$ soil.

\subsection{Assessment of enzymes activity}

Earthworms were exposed to the estimated concentrations from the initial bioassay as the median lethal concentration $\left(\mathrm{LC}_{50}\right)$ and sub-lethal concentration $\left(\mathrm{LC}_{25}\right)$ of the three insecticides for 7 days. The survival worms were homogenized in saline solution $(1: 10 \mathrm{~W} / \mathrm{V})$ and centrifuged for 30 minutes at $8000 \mathrm{rpm}$. The supernatants were used as sources of enzymes. AChE assay was performed spectrophotometrically utilizing the method of Ellman et al. (1961); the activity was expressed as $\mu$ moles acetylthiocholine hydrolyzed/ $\mathrm{mg}$ protein/minute. GST activity was determined using 1chloro-2,4dinitrobrnzene (CDNB) as substrate according to Vessey and Boyer (1984). Acid and alkaline phosphatases were estimated by the method of Bessey et al. (1946). The GABA and glutamic acid contents were determined according to Maynert et al. (1962) and Pepeu et al. (1970). Samples were analyzed for protein content according to Lowry et al. (1951).

\subsection{Statistical analysis}

Regression lines of the different pesticides $\left(\mathrm{LC}_{50}\right.$ 's) and confidence limits were calculated by probit analysis computer program according to Finney, (1971). Data of the toxicological study were analyzed by one-way 
ANOVA to determine differences between treatments (Sokel and Rohlf, 1969).

\section{RESULTS AND DISCUSSIONS}

\subsection{Toxicity Test}

Mortality has been the most frequently used parameter to evaluate the chemicals toxicity in earthworms (Liang and Zhou, 2003, Lydy and Linck, 2003). The toxicity of the tested insecticides against Lumbricus terrestirs was illustrated in Table (1).

Table1.The $\mathbf{L C}_{50}$ of the earthworm (Lumbricus terrestirs) after 7 days of artificial soil exposure to abamectin, dimethoate and malathion

\begin{tabular}{lcccc}
\hline \multirow{2}{*}{ Insecticides } & $\mathbf{L C}_{\mathbf{5 0}}$ & \multicolumn{2}{c}{$\mathbf{9 5 \%}$} & Slope \\
& $\mathbf{m g} / \mathbf{k g}$ & \multicolumn{2}{c}{ Confidence limits* } & \\
\cline { 3 - 4 } & & lower & upper & \\
\hline Abamectin & 2.99 & 2.54 & 3.51 & 2.24 \\
Dimethoate & 13.7 & 11.98 & 15.65 & 2.44 \\
Malathion & 39.69 & 34.69 & 38.49 & 6.01 \\
\hline
\end{tabular}

$* \mathrm{P}<0.05$.

The tested insecticides could be arranged according to the $\mathrm{LC}_{50}$ 's values $(\mathrm{mg} / \mathrm{kg})$ and the toxicity index as follows: abamectin> dimethoate > malathion. The data showed that abamectin was the most toxic $\left(\mathrm{LC}_{50} ; 2.99\right.$ $\mathrm{mg} / \mathrm{kg}$ ) while malathion was the least toxic $\left(\mathrm{LC}_{50} ; 39.69\right.$ $\mathrm{mg} / \mathrm{kg}$ ) on the earthworm.

The data are parallel to Mosleh et al. (2003) who reported that earthworm; Aporrectodea caliginosa is a good biomarker for soil contamination by endosulfan and aldicarb. Also the results of Hallely et al. (1993) for abamectin were parallel to the present finding, although the worms were of different genus. Aly (2005) showed that the earthworm is quite sensitive, when introduced into the soil system and could be used as a biological marker (biomarkers) for soil system contaminated with the pesticides.

\subsection{The toxicological studies}

The earthworms exposed to the contaminated artificial soil with $\mathrm{LC}_{50}$ and $\mathrm{LC}_{25}$ of the tested insecticides for 7 days were used to measure the activities of acetylcholinesterase (AChE), GlutathioneS-transferase (GST), Acid phosphatase (AcP), Alkaline phosphatase (AlP) and the neurotransmitters (gamma amino butyric acid; GABA and L-glutamic acid). Cholinesterase activity is routinely used in vertebrate animals to diagnose the exposure to organophosphates (Fairbrother et al., 1991; Edwards and Fisher 1991). In the present study, AChE activity of the treated and untreated earthworms is presented in Table (2).

The data showed that both concentrations of dimethoate and malathion had significant inhibitory effect on the AChE activity. In contrast abamectin had significant excitatory effects at the lethal and sub lethal concentrations. These data are parallel to many investigators, who showed that malathion exposure reduced AChE activity in the cerebral cortex and hippocampus. Brocardo, et al (2005) reported that like other OP compounds; malathion is known to inhibit acetylcholinesterase (AChE) activity, an effect that is thought to express the neurotoxicity elicited by these

Table 2: The Lethal effects of malation, abamectin and dimethoate on the activities of enzyme activities and neurotransmitters of the earthworm (Lumbricus terrestirs) after 7 days of artificial soil exposure

\begin{tabular}{|c|c|c|c|c|c|c|c|}
\hline \multirow{3}{*}{ Parameter } & \multirow{3}{*}{ Control } & \multicolumn{6}{|c|}{ Experimental group } \\
\hline & & \multicolumn{2}{|c|}{ Malathion } & \multicolumn{2}{|c|}{ Abamectin } & \multicolumn{2}{|c|}{ Dimethoate } \\
\hline & & LC50 & $\mathrm{LC25}$ & LC50 & $\mathrm{LC25}$ & LC50 & LC25 \\
\hline AChE & $\begin{array}{l}0.018 \pm \\
0.0005^{\mathrm{c}}\end{array}$ & $\begin{array}{l}0.013 \pm \\
0.0013^{b}\end{array}$ & $\begin{array}{c}0.01 \pm \\
0.0014^{b}\end{array}$ & $\begin{array}{c}0.035 \pm \\
0.004^{\mathrm{d}}\end{array}$ & $\begin{array}{l}0.029 \pm \\
0.0014^{d}\end{array}$ & $\begin{array}{l}0.006 \pm \\
0.0008^{\mathrm{a}}\end{array}$ & $\begin{array}{c}0.017 \pm \\
0.0^{c}\end{array}$ \\
\hline $\mathbf{A c P}$ & $\begin{array}{c}0.107 \pm \\
0.002^{\mathrm{a}}\end{array}$ & $\begin{array}{c}0.853 \pm \\
0.006^{\mathrm{g}}\end{array}$ & $\begin{array}{c}0.622 \pm \\
0.002^{f}\end{array}$ & $\begin{array}{c}0.272 \pm \\
0.006^{\mathrm{c}}\end{array}$ & $\begin{array}{c}0.213 \pm \\
0.003^{\mathrm{b}}\end{array}$ & $\begin{array}{l}0.478 \pm \\
0.0011^{\mathrm{d}}\end{array}$ & $\begin{array}{c}0.604 \pm \\
0.019^{\mathrm{e}}\end{array}$ \\
\hline AlP & $\begin{array}{l}0.08 \pm \\
0.011^{\mathrm{a}}\end{array}$ & $0.564 \pm 0.38^{\mathrm{f}}$ & $0.407 \pm 0.01^{\mathrm{e}}$ & $\begin{array}{c}0.256 \pm \\
0.0^{\mathrm{c}}\end{array}$ & $\begin{array}{c}0.211 \pm \\
0.003^{\mathrm{b}}\end{array}$ & $\begin{array}{c}0.334 \pm \\
0.016^{\mathrm{c}}\end{array}$ & $\begin{array}{c}0.333 \pm \\
0.008^{\mathrm{d}}\end{array}$ \\
\hline GST & $\begin{array}{c}0.063 \pm \\
0.003^{\mathrm{b}}\end{array}$ & $0.07 \pm 0.002^{\mathrm{c}}$ & $\begin{array}{c}0.072 \pm \\
0.005^{\mathrm{c}}\end{array}$ & $\begin{array}{c}0.064 \pm \\
0.001^{\mathrm{b}}\end{array}$ & $0.053 \pm 004^{\mathrm{a}}$ & $\begin{array}{c}0.105 \pm \\
0.001^{\mathrm{e}}\end{array}$ & $\begin{array}{c}0.084 \pm \\
0.004^{\mathrm{d}}\end{array}$ \\
\hline GABA & $\begin{array}{c}0.468 \pm \\
0.007^{\mathrm{a}}\end{array}$ & $\begin{array}{c}0.743 \pm \\
0.006^{\mathrm{b}}\end{array}$ & $\begin{array}{l}0.640 \pm \\
0.025^{\mathrm{ab}}\end{array}$ & $\begin{array}{l}0.93 \pm \\
0.015^{\mathrm{c}}\end{array}$ & $\begin{array}{l}0.72 \pm \\
0.006^{b}\end{array}$ & $\begin{array}{c}0.649 \pm \\
0.203^{\mathrm{b}}\end{array}$ & $\begin{array}{c}0.552 \pm \\
0.009^{\mathrm{a}}\end{array}$ \\
\hline L-glutamic & $\begin{array}{c}0.365 \pm \\
0.006^{\mathrm{a}}\end{array}$ & $0.633 \pm 0.02^{\mathrm{d}}$ & $0.51 \pm 0.003^{\mathrm{c}}$ & $\begin{array}{c}0.849 \\
\pm 0.01^{\mathrm{e}}\end{array}$ & $\begin{array}{c}0.630 \pm \\
0.008^{\mathrm{d}}\end{array}$ & $\begin{array}{c}0.492 \pm \\
0.005^{\mathrm{b}}\end{array}$ & $\begin{array}{c}0.483 \pm \\
0.006^{\mathrm{b}}\end{array}$ \\
\hline
\end{tabular}

Values are expressed as means $\pm \mathrm{SE} ; \mathrm{n}=5$ for each treatment group Means values within a row not sharing a common superscript letter (a-g) were significantly different, $\mathrm{p}<0.05$.

$\mathrm{AChE} ; \mu \mathrm{mol} / \mathrm{mg}$ protein/ min , AcP $\mu \mu$ moles P-nitro-phenol/mg protein $/ \mathrm{min}$,

AlP ( $\mu$ moles P-nitro-phenol/mg protein/min, GST OD/mg protein/min, GABA and L-glutamic acid

( $\mu \mathrm{g} / \mathrm{mg}$ wet tissue.) 
compounds (Kwong, 2002). Dongren et al. (2002) found that the activity of AChE was significantly inhibited in a dose and time-dependent manner when cells were exposed to dimethoate for $2 \mathrm{~h}$. AChE activity was significantly inhibited 14 and $24 \mathrm{~h}$ after application of dimethoate (Augustyniak, 2007). Oxidative stress due to dimethoate may be ascribed to the inhibition of AChE (Yukti Sharma, et al 2005). Also a research by NIH (2005) showed that farmers who used agricultural insecticides including OP's experienced increased neurological symptoms, even when they were no longer using the products (e.g. headaches, fatigue, insomnia, dizziness, nausea, hand tremors, numbness and other neurological symptoms).

GST is a very important enzyme to the earthworm because of its role as general scavenger for lipophilic xenobiotics or endogenous formed waste products in earthworms. Therefore it can be postulated that this enzyme activity can reduce the hazard of pollutants around the earthworm (Stenersen et al., 1979). The effect of the lethal and sub-lethal concentrations of the tested insecticides on GST activity of earthworms after 7 days was summarized in Table (2). The data showed that there was a significant increase's in the activity of GST after the treatment of dimethoate and malathion. On the other hand, there was a significant decrease at the LC50 of abamectin but there was a non-significant difference with $\mathrm{LC}_{25}$ of abamectin. GST activity was significantly decreased $24 \mathrm{~h}$ after application of dimethoate (Augustyniak, 2007). Oxidative stress due to dimethoate may be ascribed to the disturbance in activities of GST enzymes (Yukti Sharma, 2005). Also, malathion exposure reduced the activity of GST (Brocardo, et al. 2005). Hazarika et al (2003) found that GST activity was decreased in the liver with malathion and its combination with anilofos.

Effects of the $\mathrm{LC}_{50}$ and $\mathrm{LC}_{25}$ of the tested insecticides on AcP activity of the earthworm after 7 days are summarized in Table (2). AcP activity was significantly increased with the $\mathrm{LC}_{50}$ and $\mathrm{LC}_{25}$ of all the tested insecticides. The data showed that malathion had the highest effect on AcP activity while abamectin had the least effect. Many pesticides and metals increase the level of acid phosphatases (Abou-Donia et al. 1986, ElGendy et al. 1990)

The alteration in the activity of AlPase in whole body of the earthworm exposed for 7 days to $\mathrm{LC}_{50}$ and $\mathrm{LC}_{25}$ of the tested pesticides is presented in Table 2. The obtained results revealed that insecticides (malathion, abamectin and dimethoate) significantly increased the activity of AlPase of earthworms. The highest activity of earthworm alkaline phosphatases was noticed by malathion.

\subsection{L-glutamic acid and GABA concentrations}

On the bases of neurophysiological studies, amino acids have been separated into general classes: excitatory amino acids (glutamic, aspartic, cysteic and homocysteic), which depolarize neurons in mammalian CNS and the inhibitory amino acids (GABA, glycine, taurine and $\beta$-alanine), which hyperpolarize mammalian neurons. Strictly from a quantitative standpoint, acetylcholine and the amino acids dopamine and 5hydroxytryptamine are probably the major transmitters and probably account for transmission at only a small percentage of synaptic sites (Cooper et al., 1978). The results indicated that the lethal and sub-lethal concentrations of tested insecticides caused a significant $(P<0.05)$ induction in GABA and L-glutamic acid concentrations. The data showed that abamectin had the highest effect on the concentration of GABA and Lglutamic acid while dimethoate had the lowest effect. These results are parallel to those by El-Sayed (2004) who reported that there was an increase in the concentration of GABA and L-glutamic acid. Yamazaki et al. (1989) found that ivermectin is an agonist for the GABA concentration. Abamectin acts on gamma amino butyric acid (GABA) and glutamate-gated chloride channels, leading to activation of the chloride ion channel at higher concentrations and paralysis of pests (Putter, 1981, Bloomquist, (2001).

\section{CONCLUSION}

The present results showed that earthworm is quite sensitive to the toxicity and, could be used as biomarkers for the different groups of insecticides which are introduced into the soil system. . Also, the abamectin is more toxic than dimethoate and malathion. Accordingly, care must be taken into account to avoid the farmers and housewives' exposure to these insecticides and attention should be paid to traces of it at home environment. Also some precautions must be considered against the toxicity of these insecticides. However, although actual exposure of residents were not determined, additional studies which better estimate the residents' knowledge ,attitudes and practice as well as the potential for spray and surface contamination by insecticides.

\section{REFERENCES}

Abou-Donia, M.B., Abdo, K.M., Timmons P.R., Proctor H.E., 1986. Brain acetylcholinesterase, acid phosphatase and 2, 3 cyclic nucleotide-3-phosphohydrolase and plasma butyryl-cholinesterase activities in hens treated with single dermal neurotoxic dose of s,s,s-tri-n-butyl phosphorotrithioate. 
Toxicol. Appl. Pharmacol. 82: 461-473.

Aly, N.M., 2005. Earthworm as a biomarker for pesticides toxicity. Alex. Sci. Exchange J. 26 (4): 229-235.

Augustyniak, M. Migula, P. Mesjasz-Przybylowicz, J. Tarnawska, M. Nakonieczny, M. Babczyn'ska, A., Przybylowicz, W., 2007. Short-term effects of dimethoate on metabolic responses in Chrysolina pardalina (Chrysomelidae) feeding on Berkheya coddii (Asteraceae), a hyper-accumulator of nickel. Environmental Pollution xx 1-7.

Becker, H., Edwards, P.J., Heimbach, F. (Eds.), Ecotoxicology of earthworm. Intercept Ltd., Hant, UK, pp. 44-54.

Bessey, D.A., Lowry O.H., Brock M.I., 1946. Determination of acid phosphatase in serum with pnitrophenylphosphate. J. Biol. Chem. 164: 321-319.

Bloomquist, J. R., 2001. GABA and glutamate receptors as biochemical sites for insecticide action, in "Biochemical Sites of Insecticide Action and Resistance" (I. Ishaaya, Ed.), pp. 17-41, Springer-Verlag, Berlin.

Brocardo, S., Pablo Pandolfo, Reinaldo N., Takahashi, Ana L'ucia S., Rodrigues, Alcir L. Dafre, 2005. Antioxidant defenses and lipid peroxidation in the cerebral cortex and hippocampus following acute exposure to malathion and/or zinc chloride Toxicology 207: 283-291.

Bryan Ballantyne, Harry Salem 2006. Toxicology of organophosphate and carbamate compounds. Chapter 39Occupational Toxicology and Occupational Hygiene Aspects of Organophosphate and Carbamate Anticholinesterases with particular Reference to Pesticides. Pages 567-595. Elsevier Inc.

Campbell, W.C., Fisher, M.H., Stapley, E.O., AlbersScho“nberg, G., Jacob, T.A., 1983. Ivermectin: a potent new antiparasitic agent.Science 221, 823-828.

Charlotte N.B. Grey, Mark j. Nieuwenhuijsem, Jean Goldin, ALSPAC Team, 2006. Use and storage of domestic pesticides in UK. Science of the Total Environment vol.368, issues 2-3: pp.465-470.

Cooper, J.R., Bloomm, F.E., Roth, R.H., 1978. $\delta$ aminobutyric acid, Glycine, Glutamic acid and Taurine In: The Biochemical basis of neuropharmacology. $2^{\text {nd }}$ ed. Oxford Univ. Press, New York, pp. 223-285.

Dongren Yang, Xinfang Lu, Weiguo Zhang, and Fengsheng He., 2002. Biochemical changes in primary culture of skeletal muscle cells following dimethoate exposure. Toxicology 174: 79-85.

Edwards, C.A., Fisher S.W., 1991 The use of cholinesterase measurements in assessing the impacts of pesticides on terrestrial and aquatic invertebrates. Pp 256-275 In: Cholinesterase-inhibiting Insecticides: their Impact on Wildlife and the Environment, P Mineau (ed); Elsevier, Amsterdam.

Edwars, C.A., Bohlen, P.J., 1992. The effects of toxic chemicals on earthworms. Rev. Environ. Contam. Toxicol. 125, 23-99.

El-Gendy, K.S. Aly, N.M. Ahmed N.S.and El-Sebae A.H., 1990. Comparative toxicity of some pesticides to common carp and their effects on biochemical targets. J. pest. Cont. Envriron. Sci. 2: 29-41.

Ellman, G.L., Conurtenay, K.D., Valentino A.J., Featherstone E.M., 1961. A new rapid colorimetric determination of acetylcholinesterase activity. Biochem. Pharamaco. 7: 8895.

El-Sayed, S. (2004). Toxicological studies on the side effects of some insecticides. M. Sc. Thesis. Faculty of Agriculture, Alexandria University, Egypt.

Fairbrother, A., Marden, B.T., Bennett J.K., Hooperds M.J., 1991. Methods used in determination of cholinesterase activity. Pp 35- 72 In: Cholinesterase-inhibiting Insecticides: their Impact on Wildlife and the Environment, P Mineau (ed); Elsevier, Amsterdam.

Finney, D.J., 1971. Probit Analysis $3^{\text {rd }}$ edition. Cambridge Univ. press, London, UK pp. 318.P

Franco, M., Francesco, B., Simona M., Roberto, P., Elisabetta, P., Claudio, B., 2004. Alkaline phosphatase inhibition based electrochemical sensors for the detection of pesticides J. Electroanalytical Chem. 574: 95-100

Hallely, B.A., VandenHeuvel, W.J., Wislocki, P.G., 1993. Environmental effects of the usage of avermectins in livestock. Vet. Parasitol. 48: 109-125.

Hazarika, A.; Sarkar, S.N.; Hajare, S.; Kataria, M. and Malik, J.K (2003). Influence of malathion pretreatment on the toxicity of anilofos in male rats: a biochemical interaction study. Toxicology $185: 1-8$

Kuhle, J.C., 1983. Adaptation of earthworm population to different soil treatments in an apple orchard. In: New Trends in Soil Biology, Proc. of the 8th Intl Coll. Soil Zool. Louvain-la-Neuve, pp. 487-501.

Kwong, T.C., 2002. Organophosphate pesticides: biochemistry and clinical toxicology. Ther. Drug Monit. 24, 144-149.

Liang, J. and Zhou Q., 2003. Single and Binary-Combined toxicity of methamidophos, actochlor and $\mathrm{Cu}$ on earthworm (Esenia foetida). Ying Yong Sheng Tai Xue Bao. 14 (4): 593-596.

Lowry, O.H., Rosebrough, N.J.; Farrand A.L. and Randall R.J., 1951. Protein measurement with the folin phenol reagent. J. Bio. Chem. 193: 265-275.

Lydy, M.J., Linck S.L., 2003. Assessing the impact of triazine herbicides on organophosphate insecticide toxicity to the earthworm (Esenia Foetida). Arch ench Envron Contam. Toxicol. 45 (3): 343-349.

Maynert, E.W., Klingman, G.I. Kaji, H.K., 1962. Tolerance to morphin. II. Lack of effects on brain 5-Hydroxytyptamine and $\delta$-aminobytyric acid. J. Pharmacol. Exp. Ther., 135: 296-329.

Mosleh, Y.Y, Imail, S.M., Ahmed M.T. Ahmed Y.M., 2003. Comparative toxicity and biochemical responses of certain pesticides to the mature earthworm (Aporrectodea caliginosa) under laboratory conditions. Environ. Toxicol. 18 (5): 84-95. 
National Institutes of Health (NIH), 2005. Use of insecticides linked to lasting neurological problems for farmers. Centact: Robin Mackar 919-541-0073.

OECD. Organization for Economic Co-operation and Development,1984. Test 207: Earthworm, acute toxicity tests. In: Organization for Economic Co-operation and Development (Eds.), OECD Guideline for Testing of Chemicals.

Paoletti, M., 1999. The role of earthworm for assessment of sustainability and as bio-indicators. Agric. Ecosist. Environ. 137: 55-60.

Peakall, D.B., 1994. The role of biomarkers in environmental assessment (1). Introduction. Ecotoxicology. 3: 157-160.

Pepeu, G.; Bartolin, A., Bartolini, R., 1970. Differences of GABA content in the cerebral cortex of cats transacted at various midbrain levels. Biochem. Pharmacol., 19: 10071013.

Putter, J. G., MacConnell, F. A., Preiser, A., Haidri, A., 1981. Avermectins: Novel insecticides, acaricides and nematicides from a soil microorganism, Experientia 37, 963.

Reinecke, S.A., Reinecke, A.J., 1999. Lysosomal response of earthworm coelomocytes induced by long-term experimental exposure to heavy metals. Pedobiologia 43, 585-593.

Saint-Denis, M., Labrot, F., Narbonne J.F., Ribera, D., 1998. Glutathione, glutathione related enzymes and catalase activities in the worm (Eisenia felida) Arch. Environ. Contam. Toxicol. 35: 594-606.

Shoop, W.L., Morzik, H., Fisher, M.H., 1995. Structure and activity of avermectina and milbemycins in animal health. Vet. Parasitol. 59, 139-156.

Scott-Fordsmand, J.J., Weeks, J.M., Hopkin, S.P., 1998. Toxicity of nickel to the earthworm and the applicability of the neutral red retention assay. Ecotoxicology 7, 291295.

Sokel, R.R., Rohlf, F.J., 1969. Biometry W.H., FreemN, San Franciso.
Spurgeon, D.J., Svendsen, C., Rimmer, V.R., Hopkin, S.P., Weeks, J.M., 2000. Relative sensitivity of life-cycle and biomarker responses in four earthworms species exposed to zinc. Environ. Toxicol. Chem. 19, 1800-1808.

Stenersen, J., Guthrnberg C., Mannervik B., 1979. Glutathione-S-transferase in earthworms (Lumbriccdae). Biochem. 181: 47-50.

Svendsen, C., Weeks, J.M., 1997. Relevance and applicability of a simple biomarker of copper exposure. I. Links to ecological effects in a laboratory study with Eisenia andrei. Ecotox. Environ. Safe. 36, 72-79.

Turner, M.J., Schaeffer, J.M., 1989. Mode of action of ivermectin. In: Campbell, W.C. (Ed.), Ivermectin and Abamectin. Springer-Verlag, New York, pp. 73-78.

Vessey D.A., Boyer T.D., 1984. Different activation and inhibition of different forms of ratliver gluthathione-Stransferase by the herbicides 2,4-dichlorophenoxy acetate (2,4-D) and 2,4,5-trichlorophenoxy acetate (2,4,5-T). Toxicol. Appl. Pharmacol. 73: 492-499.

Van Gestel, C.A.M., 1991. Earthworm in Ecotoxicology. Ph.D. Thesis, University of Utrecht, p. 197.

Van Gestel, C.A.M., 1992. The influence of soil characteristics on the toxicity of chemicals for earthworm: a review. In: Greig-Smith, P.W.,

Walker, C.H., Hopkin, S.P., Sibly, R.M., Peakall, D.B., 2001. Principles of Ecotoxicology. Taylor and Francis, New York.

Yamazaki, J., Matsumoto, K., Ono, H., Fukuda, H., 1989. Macrolide comounds, ivermectin and milbemycin D, stimulate chloride channels sensitive to GABAergic grugs in cultred chich spinal neurons. Comp. Biochem. Physiol. C, 93 (1): 97-104.

Yukti Sharma, S.B., Irshad, M., Nagc, T.C., Dogra, T.D., 2005. Dimethoate-induced effects on antioxidant status of liver and brain of rats following subchronic exposure. Toxicology 215: 173-181. 


\section{الملخص العربي}

\section{دراسة مقارنه بين ملى سمية بعض مبيدات الفوسفور العضوية والأبامكتين باستخدام دودة الأرض Lumbricus terrestirs}

$$
\text { عنتر قناوى، منى شرف }
$$

$$
\begin{aligned}
& \text { • حسـوث تثبـيط معنسويا لنشـاط انزيم الاسـيتيل كـولين استيريز فن }
\end{aligned}
$$

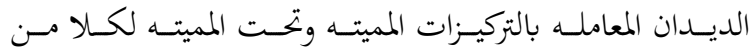

$$
\begin{aligned}
& \text { السديمثويت والملاثيـون بينمـا حســث زيادة معنويـة في نشـاط هـــا } \\
& \text { الانزيم في الديدان المعامله بالأبامكتين. }
\end{aligned}
$$

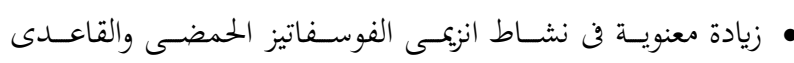

$$
\begin{aligned}
& \text { بالتركيزات المستخدمه لكل المبيدات. } \\
& \text { • زيادة نشـاط انسزيم الجلوتاثيـون- اس- ترانسفيريز زيادة معنويسة في }
\end{aligned}
$$

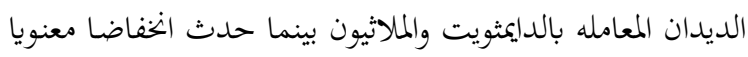

$$
\begin{aligned}
& \text { في الديدان المعامله بالابامكتين مقارنة بالعينة الضابطة. }
\end{aligned}
$$

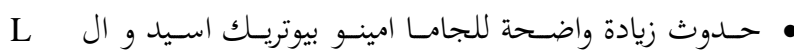

$$
\begin{aligned}
& \text { جلوتاميك اسيد في الديدان المعامله بكل المبيدات. } \\
& \text { ومس هذه النتائج يتضح أن الأبامكتين كممبيد حيوى كان اكثر } \\
& \text { سمية من المبيدات التقليدية من بجموعة الفوسفور العضوية. } \\
& \text { وكما هو معروف أن عملية شراء واستهلاك السلع الاستهلاكية }
\end{aligned}
$$

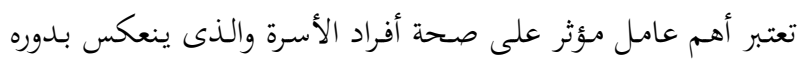

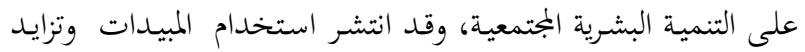

$$
\begin{aligned}
& \text { في العقد الاخير من القرن الماضى وحتى اليوم وظهر له مخاطر صحية }
\end{aligned}
$$

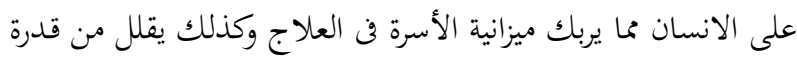

$$
\begin{aligned}
& \text { الفرد الجسميه والعقلية وكفاءته في العمل. }
\end{aligned}
$$$$
\text { استهدفت هذه الدراسة مقارنة تأثير سمية مبيد الابامكتين أحد }
$$$$
\text { افراد مجموعـة الأفرمكتين وهى مجموعـة مـن المنتجـات المتخمـرة مـن }
$$$$
\text { سلالة الاستربتوميسيس أفرميتيليس من نتاج تطبيقات البيوتكنولوجى }
$$

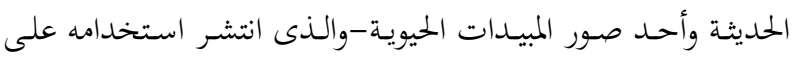$$
\text { النطاق التجارى كمبيد حيوى حديث ومقارنته بنوعين من المبيدات }
$$$$
\text { التقليديـة مـن بجموعـة الفسـفور العضـوية وهمـا الـدايمثويت والمالاثيون }
$$$$
\text { وذلك باستخدام ديـدان الارض كمؤشرحيوي لتقييم سميـة المبيـدات. }
$$

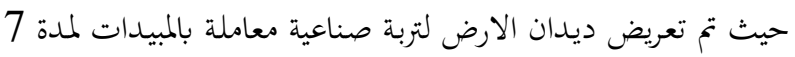$$
\text { ايام لتقدير قيمة التركيز اللازم لقتل50\% من الافراد المعاملة. وكذلك }
$$$$
\text { دراسة تاثير هـذا التركيز و نصفه على نشـاط بعض النظم الانزيمية }
$$

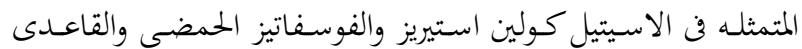$$
\text { والجلوتاثيون-أس-تراتسفيريز بالاضافة الى تقدير تركيز مستوى اثنين }
$$

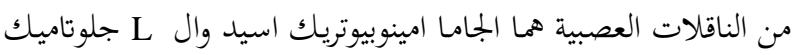

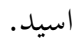

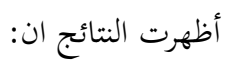$$
\text { • التركيز اللازم لقتل50\% مـ ديدان الارض لكل من الابامكتين }
$$

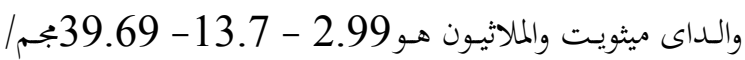$$
\text { كجم على الترتيـب مــا يوضـح أن الابامكتين كـان اكثرهم سميّة }
$$

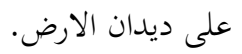

